\title{
CEOs and CFOs on IPOs: The Process and Success of Going Public
}

\author{
Martijn J. van den Assem ${ }^{1}$ • Nico L. van der Sar $^{2} \cdot$ \\ Philippe Versijp ${ }^{3}$
}

(c) The Author(s) 2017. This article is an open access publication

\begin{abstract}
We conducted 46 interviews with CEOs and CFOs who were closely involved in an initial public offering (IPO) in the Netherlands. Among other things, we find that pre-existing relationships are a primary consideration in the selection of the lead manager and other syndicate members. Pre-marketing feedback figures prominently throughout the pricing process. The width of the price range of book-built IPOs is especially driven by valuation uncertainty. There is evidence of strategic underpricing in anticipation of subsequent equity issues and because of management's interest in satisfying new shareholders. Many interviewees believe that the lead manager's business interests have had a strong influence on the allocation of shares. Managerial perceptions of IPO success are largely driven by how well the firm fared in terms of stock price performance, changes in media attention and visibility, and changes related to the retention and recruitment of staff.
\end{abstract}

We are indebted to the many CEOs and CFOs who participated in our survey-without their donation of valuable time this paper could not have been accomplished. We thank Roeland Haanen, Geert-Jan van Logtestijn and Coen Mensink for their constructive comments, and to Jeffrey Duyvesteijn, Robartus Krol and Lars van Dort for their skillful research assistance.

$凶 \quad$ Martijn J. van den Assem

m.j.vanden.assem@vu.nl

Nico L. van der Sar

vandersar@ese.eur.nl

Philippe Versijp

p.j.p.m.versijp@uva.nl

1 Faculty of Economics and Business Administration, Vrije Universiteit Amsterdam, De Boelelaan 1105, 1081 HV Amsterdam, The Netherlands

2 Erasmus School of Economics, Erasmus University Rotterdam, Rotterdam, The Netherlands

3 Faculty of Economics and Business, University of Amsterdam, Amsterdam, The Netherlands 
Keywords Initial public offering - Survey - Going public - IPO process - IPO success · Valuation · Lead manager · Syndicate $\cdot$ Pre-marketing $\cdot$ Book building

JEL Classification G30 · G32 - G34

\section{Introduction}

An initial public offering (IPO) is generally seen as a major event in a firm's development. Traditionally, empirical research into IPOs has largely focused on the underpricing and aftermarket performance of the shares (Jenkinson and Ljungqvist 2001; Ritter and Welch 2002; Ritter 2003a). More recently, there has been an increasing interest in subjects related to the process and decisions that precede the first day of listing, such as the motives for going public (Pagano et al. 1998; Kim and Weisbach 2008), selecting an underwriter (Schenone 2004; Fernando et al. 2005), syndicate formation (Corwin and Schulz 2005; Cooney et al. 2015), and the price-setting process (Lowry and William Schwert 2004; Lowry et al. 2010). This branch of IPO research mostly employs firm characteristics and market conditions as proxies for the forces that are believed to drive these aspects. Disadvantages of such a method are the indirectness and limited scope due to data constraints.

The present study takes an alternative approach to provide insights into the process of going public: we employ interviews with CEOs and CFOs who were closely involved in an IPO, and ask these executives about their views on key aspects of the IPO process and why and how various decisions were made. Our questions among other things relate to the lead manager choice and syndicate formation, the pricing process, the allocation of shares, and the roles of private equity and venture capital. Also, we ask the CEOs and CFOs for their sentiment-in retrospect- towards the success of the IPO and we examine the factors driving their evaluation.

With our interviews we complement an excellent but relatively small body of related survey studies. Baker and Johnson (1990) use a questionnaire to examine managerial motives for listing and not listing in the US. Ravasi and Marchisio (2003) investigate the implications of going public, using seven case studies with personal interviews and a questionnaire that was distributed among companies that went public in Italy. The British studies by Burton et al. $(2004,2006)$ use a questionnaire supplemented by ten interviews with managers and advisors; their first study focuses on corporate governance changes, whereas the second is more general, with an emphasis on the advantages and disadvantages of going public. von Eije et al. (2004) study IPO-related organizational changes; in an interview-like setting they had managers of 27 Dutch companies that went public in the Netherlands or abroad in the period 1987-1997 fill in a questionnaire. Brau et al. (2006), Brau and Fawcett (2006a) and Bancel and Mittoo (2009) use questionnaires among CFOs-from the US, the US and Europe, respectively - to compare managerial motivations for conducting an IPO with academic theories on why firms go public. Brau and Fawcett (2006a) in addition consider underwriter selection, underpricing and signaling - areas that are also examined in the present paper (see also Brau and Fawcett 2006b). 
Our work differs markedly from these studies in terms of both scope and method. First, we examine a large variety of managerial aspects of the IPO process, whereas the emphasis of earlier studies is on the decision and implications of going public. To the best of our knowledge, most of the issues that we address have not been covered by previous CEO/CFO surveys. Our study is also the first to systematically examine managerial views on the determinants of IPO success. Second, we use in-person, one-to-one interviews, whereas the previous studies are primarily based on mail questionnaires. Our interviews were semi-structured through a uniform set of questions, with the flexibility to discuss interesting responses in more detail. Many questions were open-ended to leave room for unanticipated views and experiences. Important advantages of this approach are in the quality and completeness of the collected information. Furthermore, unlike mail questionnaires, the personal interviews enable us to guarantee that respondents were truly key executives who had been closely involved in the IPO process.

A downside of in-person interviews is that they put a limit to the potential scale and geographical scope. We focus on all IPOs that took place in the period 1990-2008 in the Netherlands. In total we conducted 46 interviews, for a response rate of 57\%. This relatively high rate is probably the result of the personal nature of both the interview itself and our request to participate. Most interviewees were the CEO at the time of the IPO, and for convenience and brevity we henceforth refer to them as "CEOs".

Our main results can be summarized as follows. The average IPO process lasts 6-7 months. Lead managers are primarily selected because of relational and expertiserelated aspects, while analyst coverage, fees and valuation indications are relatively unimportant. Issuing firms' preferences for the other syndicate members are especially driven by characteristics of the investor client base and by established business relationships. Most CEOs were aware of potential conflicts of interest between the issuing firm and the lead manager, and they actively negotiated about the offer price; at the same time many of them also acknowledge that they did not strive for the highest possible price because of the interest they had in satisfying new shareholders. The interviews provide some evidence of strategic underpricing in anticipation of subsequent equity issues.

Pre-marketing feedback is figuring prominently throughout the pricing process. The width of the price range of book-built IPOs is primarily driven by uncertainty about the value of the shares. IPOs are rarely priced above the upper bound of the price range, but about half of the interviewees think that the lead manager would have been prepared to do so. Issuing firms play an active but subordinate role in the allocation of shares, and many CEOs believe that the lead manager's business interests have had a strong influence on the allocation strategy.

CEOs are positive about the overall success of the IPO from the perspective of the firm. The key factors driving their evaluation are how well the firm fared in terms of stock price performance, changes in media attention and visibility, and changes related to the retention and recruitment of staff. These factors are mentioned by the CEOs themselves when we directly ask for the critical success factors, and the same factors also emerge more indirectly when we first ask the CEOs to evaluate a list of pre-specified factors and then regress their overall success ratings on the ratings for these factors. 
The remainder of the paper is organized as follows. Section 2 describes our survey design and the sample. Section 3 presents the results related to the IPO process, subdivided into duration and organization, lead manager choice and syndicate formation, pricing, allocation, and private equity and venture capital. Section 4 presents our results on the evaluation of IPO success. Section 5 summarizes and concludes.

\section{Setup and Sample Description}

Our study focuses on the Dutch IPO markets-operated by the exchange formerly known as Amsterdam Exchanges and now part of Euronext-in the period 19902008. The target population for this time frame comprises 81 IPOs (after excluding new listings of preference shares, foreign companies, investment companies, acquisition funds, shares of companies that had a listing at some point during the preceding 5 years, and offerings of units comprised of both common stocks and other securities).

For each qualifying IPO we investigated which current or former CEO or CFO had most likely been closely involved. In 74 cases we sent this executive a letter that explained our study, asked for an in-person interview of approximately $1 \mathrm{~h}$, promised anonymity, and announced a follow-up telephone call. If our first attempt was not successful we tried again with another then-executive. In 7 cases we either could not trace the required contact details or deliberately refrained from an interview request because all qualifying executives were residing abroad.

A total of 45 executives agreed to be interviewed. Together they had been involved in 46 different IPOs, or $57 \%$ of our target population. ${ }^{1}$ Lack of time was the most frequent reason for not meeting our request. Some refused without any explanation, others turned out to be living abroad or did not respond. Figure 1 shows that the participation rate is fairly constant through time, and that about half of the IPOs took place in the late 1990s with a peak in 1998. The market came to a halt during the dot-com crisis, with some recovery before the credit crisis hit in 2007. After 2008 the IPO volume remained low, with only four qualifying IPOs in 2009-2014. The overall pattern and prolonged drought in IPOs since 2000 are in line with international developments (Gao et al. 2013). A first round of 40 interviews took place in 2002, and 6 more were held in 2008. More than $70 \%$ (71.7\%) of the IPOs had happened in the period of 5 years prior to the year of the interview. Only in three cases $(6.5 \%)$ the IPO had taken place more than 10 years earlier.

Table 1 provides some descriptive statistics for the IPOs in our sample. Most listings $(36 ; 77 \%)$ were on the main or "official" market. The other companies $(10 ; 23 \%)$ had been admitted to one of the alternative markets (Parallel Market, NMAX/Euro.NM, Alternext). As with most IPOs across the globe, book building was the most frequently employed issue method $(35 ; 76 \%)$. Mann-Whitney $U$ tests indicate that our sample companies issued a smaller percentage of new shares, generated a lower initial return, and are older than the companies not in our sample (all $p<0.05$ ). In terms of transaction size, public float percentage, sales in the last fiscal year, total assets and

\footnotetext{
1 One CFO had been working on two different IPOs. In a double-length interview, we went over each IPO separately. We take this case as two interviews with two different respondents on two different IPOs.
} 
20

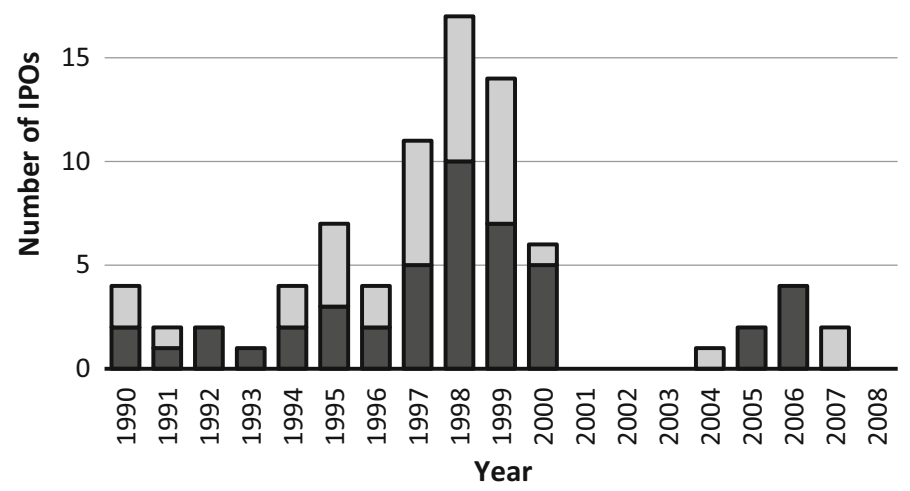

Fig. 1 IPOs in the Netherlands, 1990-2008. The figure displays the number of IPOs on the Dutch stock markets for each year in the period 1990-2008, subdivided into IPOs included (darker part bars) and IPOs not included (brighter part) in our survey sample

number of employees, the IPOs in our sample are statistically indistinguishable from the IPOs not in our sample (all $p>0.40$ ).

Virtually all interviewees were either the CEO $(28 ; 61 \%)$ or the CFO $(16 ; 35 \%)$ at the time of the IPO. ${ }^{2}$ Two-thirds $(30 ; 65 \%)$ were still affiliated with the company when the interview took place. All are male.

All CEOs had been closely involved in the IPO process. Without exceptions, they spoke vividly about their IPO during the interview and they appeared to recall many aspects of the "milestone event" in their career in detail. Most sessions lasted longer than the scheduled (but normally adequate) 1-h time slot, mostly because we did not want to cut short enthusiastic elaborations when the respondent seemed not to care about time.

Most interviews were audio-recorded and then transcribed. Detailed notes were made otherwise. To ensure comparability, we structured all interviews on the basis of a uniform set of questions (spelled out in the "Appendix"). The order in which the various topics were discussed was not fixed, but depended on how the conversation unfolded. The number of responses underlying the statistics reported in the next sections differs across questions due to cases where a question was not applicable, cases where the respondent could not recollect the relevant details, and cases where a question was not asked by mistake or due to time constraints (the "Appendix" gives an overview of the numbers). To prevent possible misunderstandings, relatively complex questions were also presented in print, and if we were not sure that a question was properly interpreted we repeated or reformulated it. Whenever relevant or potentially interesting, we asked for more elaborate answers or went deeper into specifics. Perhaps supported by the anonymity that we had promised, respondents were seemingly frank and open with us.

2 One non-CEO/CFO was secretary to the board when the IPO took place, and the other was an external investor relations advisor who was later employed by the company. 
Table 1 Descriptive statistics

\begin{tabular}{llll}
\hline & Included & Not included & Population \\
\hline Number of IPOs & & & 81 \\
Overall & 46 & 35 & $63(78 \%)$ \\
On the main market & $36(77 \%)$ & $27(78 \%)$ & $18(22 \%)$ \\
On an alternative market & $10(23 \%)$ & $8(22 \%)$ & $64(79 \%)$ \\
Using the book-building method & $35(76 \%)$ & $29(83 \%)$ & $14(17 \%)$ \\
Using the fixed-price method & $9(20 \%)$ & $5(14 \%)$ & $3(4 \%)$ \\
Using the rights method & $2(4 \%)$ & $1(3 \%)$ & $240(56)$ \\
Offer characteristics & & & $43.7(40.4)$ \\
Size & $282(48)$ & $185(68)$ & $34.5(33.3)$ \\
Primary shares $(\%)$ & $36.0(24.1)$ & $53.8(55.1)$ & $14.0(3.7)$ \\
Public float $\%)$ & $34.1(30.0)$ & $35.0(34.2)$ & $16.7(9.0)$ \\
Initial return $(\%)$ & $11.9(1.9)$ & & $455(64)$ \\
Company characteristics & & $204(62)$ & $1333(57)$ \\
Revenues & $646(91)$ & $251(50)$ & $3098(500)$ \\
Total assets & $2132(62)$ & $1517(808)$ & $31.5(14.0)$ \\
Employees & $4301(435)$ & $23.6(9.0)$ & \\
Age & $37.5(16.0)$ & & \\
\hline
\end{tabular}

The table presents descriptive statistics for the IPOs included in our survey sample, for the IPOs not included in our survey sample, and for the entire population of IPOs in the Netherlands in the period 1990-2008. The statistics relate to the numbers of IPOs across types of markets and pricing methods (proportions between parentheses) and to offer and company characteristics (mean values; median values between parentheses). Size is the number of shares on offer times the offer price (assuming no exercise of the overallotment option). Primary shares is the number of newly issued shares as a percentage of the total number of shares on offer (assuming no exercise of the overallotment option). Public float is the number of shares on offer as a percentage of the number of shares outstanding after completion of the IPO (assuming no exercise of the overallotment option). Initial return is the difference between the first-day closing price and the offer price, expressed as a percentage of the offer price (for rights offerings we assume the offer price is equal to the sum of the exercise price and the first closing price of the rights divided by the conversion rate). Revenues is the company's sales in the last fiscal year in the IPO prospectus. Total assets is the sum of all (fixed and current) assets at the end of the last fiscal year reported in the IPO prospectus. Employees is the most recent number of employees according to the IPO prospectus. Age is the number of years until the IPO date after the company was founded or a predecessor started its operations (whichever was earliest). Monetary amounts are in millions of Euros

\section{The IPO Process}

\subsection{Duration and Organization}

We define the process of going public as the aggregate of all IPO-related activities and events that take place in the time interval between the selection of the lead manager and the first day of public trading. Elements include lead manager selection and syndicate composition, due diligence research, the writing of a prospectus or offer memorandum, the listing application, the pricing process and marketing activities, the subscription process, and the allocation of shares. 
After explaining our definition, we asked CEOs for the length of the IPO process. The raw average response was 7.5 months. In $16 \%$ of the cases the listing had been postponed (for an average of 3.5 months) because of adverse financial market conditions or a time-consuming acquisition by the company. After controlling for postponement and after excluding an extreme observation of 29 months, the average (median) length of the IPO process is 6.4 (6.0) months. Going public took somewhat longer for firms larger than the median sample firm than for smaller ones (approx. 7 vs. 6 months; $p<0.10)$.

The IPO process was always (co-)directed by one or more executive directors of the firm, while external shareholders mostly took a passive role. ${ }^{3}$ In $74 \%$ of the cases, the process was led by executive directors alone $(70 \%)$ or joint with one or more independent non-executive directors (4\%). External shareholders were actively involved in negotiations and decisions only $26 \%$ of the time. Controlling for firms with no external shareholders prior to the listing, this percentage is $32 .{ }^{4}$ When external shareholders took a passive role, executive directors together mostly $(76 \%)$ held more than $5 \%$ of the firm's outstanding shares.

\subsection{Lead Manager Choice and Syndicate Formation}

The choice of a lead manager is a major decision, as this investment bank plays an important role in many of the key aspects of the IPO process. In 64\% of the cases the lead manager was selected through a so-called beauty contest, where multiple teams of investment bankers one by one present themselves and their offer to the company. Mostly, four or five banks took part (mean: 4.6; minimum: 3; maximum: 7). Another $20 \%$ of the time there was no real choice process, because no more than one investment bank had been in the picture; the sole candidate was mostly an existing business connection of the company then. In addition, $16 \%$ of the CEOs indicated that they have talked with multiple banks, but did not organize the selection of the lead manager as a formal beauty contest. Normally, the company contacted the potential lead manager; in only $18 \%$ of the cases one or more banks approached the company.

We asked all CEOs for the most important considerations in their lead manager choice. Table 2 gives an overview of the categorized responses. The most frequently mentioned reasons are an already existing relationship (30\%), the investment bank's reputation, experience or professionalism (24\%), its specific industry expertise or experience with similar IPOs $(22 \%)$, its investor client base $(22 \%)$, the perception of a favorable balance of power (22\%), and interpersonal chemistry or "fit" (17\%). When the lead manager was chosen because of a pre-existing relationship, half of the

\footnotetext{
3 We define an external shareholder as a shareholder other than an executive director, a non-executive director or a founder.

4 There is some evidence that the involvement of external shareholders depends on the composition of the offering. For IPOs with an external shareholder prior to the listing $(N=37)$, the median proportion of secondary shares is $76.6 \%$. The percentage of IPOs where external shareholders were actively involved is 22 for below-median cases and 42 for at- or above-median cases $(p=0.197)$. External shareholders were never actively involved when no existing shares were sold $(N=7)$, whereas the percentage is 40 when secondary shares were on offer $(N=30 ; p=0.041)$.
} 
Table 2 Lead manager choice

\begin{tabular}{|c|c|c|c|}
\hline & Nos. & $\%$ raw & $\%$ adj. \\
\hline \multicolumn{4}{|l|}{ Expertise } \\
\hline $\begin{array}{l}\text { Reputation (including general experience } \\
\text { and professionalism) }\end{array}$ & 11 & 23.9 & 14.1 \\
\hline $\begin{array}{l}\text { Specific industry expertise, experience with } \\
\text { similar IPOs }\end{array}$ & 10 & 21.7 & 11.1 \\
\hline Investor client base & 10 & 21.7 & 11.4 \\
\hline \multicolumn{4}{|l|}{ Relational aspects } \\
\hline Balance of power, commitment & 10 & 21.7 & 12.9 \\
\hline Chemistry, interpersonal fit & 8 & 17.4 & 9.2 \\
\hline Pre-existing relationship & 14 & 30.4 & 21.6 \\
\hline \multicolumn{4}{|l|}{ Financial aspects } \\
\hline Fees, other costs & 2 & 4.3 & 1.8 \\
\hline Preliminary valuation & 1 & 2.2 & 0.5 \\
\hline \multicolumn{4}{|l|}{ Other } \\
\hline Lack of alternative candidates & 3 & 6.5 & 5.1 \\
\hline Proposed speed of IPO execution & 2 & 4.3 & 4.4 \\
\hline Proposed action plan (in general) & 6 & 13.0 & 6.9 \\
\hline Nationality (apart from investor client base) & 1 & 2.2 & 1.1 \\
\hline
\end{tabular}

The table gives an overview of the responses when we asked for the most important considerations in the lead manager choice. The first column lists the categories of responses, the second column shows the frequencies of the various types of responses, and the third column expresses the frequencies as a percentage of the number of respondents. CEOs often brought forward multiple reasons; the last column presents relative frequencies that control for this by weighting each observation by the reciprocal of the total number of considerations that a respondent mentioned. $N=46$

times the lead manager was already serving as the firm's company bank. In the other occasions there were personal ties, or the bank was a shareholder or had been involved in a prior investment banking transaction. ${ }^{5}$

Fees and other costs (4\%) and preliminary valuation outcomes (2\%) turn out to be relatively unimportant. Analyst coverage was never explicitly mentioned as a primary concern. This contrasts with US practice (Krigman et al. 2001; Brau and Fawcett 2006a; Francis et al. 2010), and may explain why "there is relatively little research using European data examining the role of analysts in the IPO process" (Ritter 2003b).

CEOs often brought forward more than one reason (average: 1.7). The last column of Table 2 controls for this by weighting the responses by the reciprocal of the total number of considerations mentioned. The conclusions remain the same: lead managers are

\footnotetext{
5 Schenone (2004) presents empirical support for her hypothesis that established relationships reduce asymmetric information problems behind IPO underpricing. Our data also point in this direction: the average (median) initial return is $5.0(0.7) \%$ for IPOs where an established relationship was among the most important considerations in the lead manager choice, and 14.9 (3.4) for the other IPOs. Possibly due to lack of power the difference is, however, statistically insignificant.
} 
primarily selected because of relational aspects (44\% in total) and perceived expertise $(37 \%)$.

The importance of alignment of interests and interpersonal fit suggest that the matching of issuing firms and lead managers is based on firms' and underwriters' relative characteristics at the time of issuance (Fernando et al. 2005), while the importance of established relationships suggests that firms are trying to avoid asymmetric information problems (Schenone 2004).

The weight of the expertise-related aspects is in line with survey results for US IPOs (Brau and Fawcett 2006a) and with survey results for firms that completed an IPO and then switched underwriters in follow-on equity offerings (Krigman et al. 2001).

Even though reputation is the second most often mentioned main consideration in the lead manager choice, the majority did not cite it. Despite this, $77 \%$ did agree with the proposition that the name or reputation of the lead manager has a positive influence on the offer price. The remaining 23\% disagree, including one respondent who believes that the relation is negative: banks would have an interest in a low offer price because they want the IPO to take place and be successful, and more reputable banks are better able to take a firm line.

Costs are hardly ever mentioned as a critical factor, but CEOs do turn out to care about the transaction fee: $88 \%$ have negotiated with the lead manager over the gross spread that was to be paid to the lead manager and the other syndicate members. Apart from some exceptions, they indicated that these negotiations were fruitful and led to a reduced rate (specific reductions that we recorded range from 0.25 to $2 \%$ points). This picture complements the comparison of US and European IPO fees by Abrahamson et al. (2011) and their finding that the "gross spread" in Europe does not cluster and is substantially lower than the gross spread in the US. Although we did not investigate the precise levels of the ultimate fee, the interviews yielded some evidence that US investment bankers are charging a higher rate than their Dutch peers and that they are less willing to argue over it. ${ }^{6}$

Normally, U.S. investment banks are absolutely not willing to deviate from a rate of seven percent. Ours indicated that a lower fee was possible, but seven percent nevertheless needed to be disclosed in the prospectus. The difference would then be repaid at a later time. In the end, five percent was agreed upon.

At first the U.S. investment bank did not want to do the deal for the fee that we had proposed. They had never done that, and the news would spread like wildfire in the market. In the end we got what we wanted, although we had to pay a little more than we initially aimed for.

We also discussed how other syndicate members were chosen. The syndicate is the group of banks that work together to market the IPO. This topic was not applicable to nine relatively small firms where only one investment bank had been involved in the IPO. We asked our respondents whether they have exerted influence on the composi-

6 We illustrate some findings with quotes from CEOs. For the sake of anonymity, quotes that would reveal the identity of the interviewee or his firm have been (slightly) edited. Multiple quotes on one subject are always from different CEOs. 
Table 3 Syndicate formation

\begin{tabular}{lcrr}
\hline & Nos. & \% raw & $\%$ adj. \\
\hline Investor client base & & & \\
Investor client base in general & 11 & 33.3 & 17.7 \\
Retail investor client base & 5 & 15.2 & 10.6 \\
Institutional investor client base & 3 & 9.1 & 3.3 \\
National or regional investor client base & 8 & 24.2 & 11.9 \\
International investor client base & 3 & 9.1 & 4.6 \\
Relational aspects & & 54.5 & 32.1 \\
Pre-existing relationship & 18 & 3.0 & 1.0 \\
Relationships among syndicate members & 1 & & 4.8 \\
Other & & 12.1 & 14.1 \\
Equity research (quality, commitment) & 4 & 27.3 & \\
Impression made in beauty contest for lead manager role & 9 & & \\
\hline
\end{tabular}

The table gives an overview of the responses when we asked the CEOs who have had an influence on the syndicate composition for their considerations in proposing or selecting syndicate members. Columns are defined as in Table 2. $N=33$

tion of the syndicate. A large majority of $92 \%$ have done so, while the remaining $8 \%$ left the formation to the lead manager. We then asked those involved in composing the syndicate for their considerations. The results are summarized in Table 3. Investor client base turns out to be an important factor: $82 \%$ (not tabulated) named at least one investor client base related reason. Some pointed specifically at syndicate members' connections with retail, institutional or foreign investors. Pre-existing relationships are the second most important factor: $55 \%$ preferred a bank to be part of the syndicate because it was the firm's principal bank, an important customer, shareholder or lender, or because of personal relationships or prior investment banking services. The impression that a bank made in the beauty contest for the lead manager role is the third most important reason, and brought forward by $27 \%$. Controlling for IPOs with no beauty contest, $41 \%$ proposed or selected a bank for this reason. The perceived quality of a bank's equity research plays a minor role (12\%).

Corwin and Schultz (2005) find evidence that relationships between investment banks are playing a critical role in the composition of US syndicates, and they argue that these are important because they mitigate moral hazard problems. A similar reasoning may explain why pre-existing relationships with candidate syndicate members are important for issuing firms.

\subsection{Pricing Process}

As discussed in the previous section, preliminary valuation indications are hardly ever mentioned as an important factor in the lead manager selection process. Still, the bank's valuation or pricing ideas are in most cases tabled at that early stage: $70 \%$ answered affirmatively when we asked whether the pricing of the shares had already 
been discussed with the lead manager at the time the lead manager was hired. Only in $20 \%$ of these cases (14\% of all IPOs) the CEO pointed out that a formal agreement had been made about a minimum price or a range. In the other cases, the early pricing talks lead to no more than a non-binding indication of the valuation or offer price. In $30 \%$ of the IPOs, valuation or pricing did not come up before the lead manager had been selected.

Four CEOs who had discussed the valuation with the lead manager at the start of the process reported spontaneously that the lead manager's first valuations or pricing indications were substantially more favorable than the ultimate price or price range. They felt the bankers had been extraordinarily positive about the value of the company, because they were still pitching for the mandate at that time. Two CEOs who did not discuss valuation or pricing early on added that they thought that doing so would not have made any sense for exactly this reason.

It is a game. Everybody knows that their indicative valuation range is much higher than the final price. The bank then still has to win the deal. Once they have it, the range goes down.

Early valuation outcomes are thus mostly non-binding, and the picture emerging from the interviews is that issuing firms are generally aware of the "bait-and-switch" problem, where investment banks present high valuations when they pitch for the IPO mandate and revise these downwards when the final price or price range is to be set and the issuing firm is locked in (Jenkinson and Jones 2009b).

After the lead manager choice, for all IPOs a more formal "desk" valuation exercise was carried out as one of the first steps in the pricing process (market multiples, discounted cash flow analysis; see also Bancel and Mittoo (2014), for a survey demonstrating the prominence of these two approaches in the theory and practice of corporate valuation). Mostly the bank took the lead in the desk valuation, but $85 \%$ of the time the company or its shareholders were closely involved in a role that varied from commenting on the bank's input parameters or findings to bringing up a specific valuation approach. For $15 \%$ of the IPOs the bank carried out the desk valuation on its own. About half of the times when the company or its shareholders were involved, an external party or syndicate member was called in for a separate valuation or fairness opinion.

The process of setting the offer price comprises more than a static valuation exercise. Although the first pricing indications are mostly being generated at the start of the IPO process, the actual offer price (in fixed-price IPOs) or price range level (in book-built IPOs) is being established only shortly before it is made public. 53\% of the CEOs indicated that there were no more than 2 days between the decision about the price or price range and its publication in the (preliminary) prospectus. In the remaining cases, the interval was between 2 days and 1 week (13\%), between 1 and 2 weeks (13\%), between 2 weeks and 1 month (18\%), or longer (5\%).

We asked CEOs for the factors that led to changes in the expected offer price (in fixed-price IPOs) or price range level (in book-built IPOs) throughout the pricing process. Table 4 summarizes the responses. On average, respondents listed 2.4 determinants. Changing expectations were especially driven by new or renewed insights from pre-marketing (74\%) and desk valuations (76\%). By pre-marketing the IPO 
Table 4 Determinants of changes in the expected offer price

\begin{tabular}{lrrr}
\hline & Nos. & $\%$ raw & $\%$ adj. \\
\hline New insights from valuation models & 32 & 76.2 & 35.3 \\
Company-specific developments and changed prospects & 5 & 11.9 & 3.3 \\
Stock market developments and sentiment & 16 & 38.1 & 13.7 \\
Pre-marketing feedback & 31 & 73.8 & 30.7 \\
Intuition, situational awareness & 3 & 7.1 & 4.0 \\
Negotiations & 15 & 35.7 & 13.1 \\
\hline
\end{tabular}

The table gives an overview of the responses when we asked for the factors that have led to changes in the expected offer price (in fixed-price IPOs) or price range level (in book-built IPOs) throughout the pricing process. Columns are defined as in Table 2. $N=42$

among large investors, the lead manager obtains information about interest in the IPO before the offer price or price range is fixed and disclosed (and subscription formally starts). ${ }^{7}$ CEOs who pointed at the influence of valuation models especially stressed the important role of trading multiples of peer companies. Furthermore, 38\% indicated that stock market developments and sentiment were changing the pricing expectations. As multiple respondents acknowledged, market conditions can also have an indirect influence on the pricing process, for example through market multiples and pre-marketing demand. Negotiations with the lead manager make up the fourth significant factor of influence (36\%). Interestingly, when we tabled this question, several CEOs complained that the lead manager had not been transparent about pre-marketing activities.

The bank was mysterious about pre-marketing. We know that pre-marketing activities have taken place, because the road shows were cancelled because of enormous demand.

The bank denies that they have conducted pre-marketing activities, but I do not believe that. Those scamps know in advance where the shares are going! For each bank I know which institutional investors they will come up with. They all have their own clientele.

We were also interested in the factors that determined the width of the price range of book-built IPOs. Table 5 gives an overview. The great majority of respondents came up with one or two factors (mean: 1.5). More than half of the CEOs (56\%; not tabulated) made one or more direct references to uncertainty about the market value of the IPO shares: $22 \%$ mentioned the uncertainty surrounding desk valuation outcomes, $28 \%$ cited the uncertainty appearing from pre-marketing feedback, and $16 \%$ pointed at uncertainty about the market value of the shares in general. More indirectly, 28\% believed that the width reflected uncertainty about short-term stock market developments: the range was set such that it normally could accommodate market fluctuations

\footnotetext{
7 The influence of pre-marketing appears to be similar for fixed-price and book-built IPOs: pre-marketing feedback is brought forward for $67 \%$ of the fixed-price IPOs and for $76 \%$ of the book-built IPOs.
} 
Table 5 Determinants of the width of the price range

\begin{tabular}{lccc}
\hline & Nos. & $\%$ raw & $\%$ adj. \\
\hline General uncertainty about market value shares & 5 & 15.6 & 8.3 \\
Uncertainty based on desk valuation outcomes & 7 & 21.9 & 16.7 \\
Uncertainty based on pre-marketing information & 9 & 28.1 & 18.8 \\
Uncertainty about short-term stock market developments & 9 & 28.1 & 19.8 \\
Negotiations or disagreement with lead manager & 7 & 21.9 & 15.6 \\
Preference for final offer price at top of range & 2 & 6.3 & 2.6 \\
Width of the price range in other IPOs & 5 & 15.6 & 8.9 \\
Intuition, situational awareness & 2 & 6.3 & 4.7 \\
Unknown considerations of lead manager & 3 & 9.4 & 4.7 \\
\hline
\end{tabular}

The table gives an overview of the responses when we asked the CEOs who had been involved in a bookbuilt IPO for the factors that have influenced the width of price range. Columns are defined as in Table 2. $N=32$

during the subscription period. In $22 \%$ of the IPOs, the width was affected by negotiations or disagreement between the firm and the lead manager; adopting a wider range allowed for incorporating diverging views about the appropriate price. Finally, $16 \%$ felt comfortable with a width that they considered to be "common practice", $6 \%$ relied on the bankers' intuitive judgments, $6 \%$ chose the range strategically such that the final offer price could be set at the top of the range, and in $9 \%$ of the cases the range was set according to unknown considerations of the lead manager.

The answers to our questions about intermediate changes in expected pricing and the width of the price range already revealed that many firms do not shrink from negotiating with the lead manager. We have also directly asked our respondents whether they have entered into a debate with the bank about the pricing of the shares, and requested them to express the intensity of this debate on a five-point scale. A total of $86 \%$ indicated that medium $(23 \%)$, considerable $(30 \%)$ or strong $(33 \%)$ negotiations had taken place. Relatively few labeled the intensity of their negotiations as moderate $(12 \%)$ or said that there had not been any pricing negotiations (2\%). Most CEOs are satisfied with the line they took: only $14 \%$ admitted-with hindsight - that they wish they had negotiated (even) stronger on pricing.

At a given moment you are locked in, various things are already planned by then. Given what I know now about how the financial world works, I would have negotiated on various issues at an earlier stage. After all, it is a weird world with its brokers, fund managers, portfolio managers, analysts, et cetera.

This picture of a relatively firm stance is reinforced by the finding that $69 \%$ of the CEOs confirmed that they have been aware of a conflict of interest between the company and the lead manager during the pricing process. Among the remaining 31\%, two CEOs explained that the ambition of the bank to become an established listing agent had prevented such tensions. Two others thought that the conflict of interest worked the other way around, and explained that the bank favored a higher price either because of their relation with the selling shareholders or because of their percentage commission. Unawareness of a conflict of interest between company and lead manager might 
also be related to the principal-agency relation between management and pre-deal shareholders that unexpectedly came up in nine different interviews: members of the board of directors are not inclined to get the maximum out of the IPO for existing shareholders, because they will have to deal with the new shareholders after the IPO as well.

The bank tried to carry out the IPO as prudently as possible. It was in the board's interest not to sell at a high price, but we have nevertheless helped the selling shareholder a bit. When the bankers became overly pessimistic we told them not to exaggerate.

In line with the pricing of IPOs in other European countries (Jenkinson et al. 2006), the 35 book-built IPOs in our sample were rarely priced below (one exception, or 3\%) or above $(3 \%)$ the initial price range, despite its non-binding character. Also, a relatively large fraction of $49 \%$ were priced exactly at the top of the range. To understand how the range may restrain the final offer price in the pricing process, we asked the CEOs whether they would have gone along with an offer price below the initial price range if the bank had proposed to do so. A majority of $60 \%$ of the CEOs involved in a book-built IPO claimed that they would have refused this. Some added that they were highly confident that the initial pricing had been correct, that shareholders would have opposed a lower price, or that the bank then would have been to blame. The other $40 \%$ stated that they would not have been resolutely against an offer price below the initial price range. Half of them voluntarily added that the bank would have had to present good arguments for it.

Similarly, we asked whether they believe the bank would have been willing-of its own accord or upon request - to set the offer price above the initial price range if investor demand would have given rise to it. $44 \%$ thought that the bank would indeed have been prepared. Their assessments contrast with the role of the price range as a commitment device that is required for information production in the pre-marketing stage (Jenkinson et al. 2006). A small majority of 56\% believed that the bank would have played no part in it. Whenever the latter respondents elaborated their view, they virtually always indicated that setting the offer price above the range is regarded as improper or harming the bank's reputation of trustworthiness. In line with the institutional differences discussed in Jenkinson et al. (2006), three CEOs tabled their belief that US investment banks are more flexible than European investment banks in this respect. We also asked CEOs whether or not they agree with the statement that setting the price above the initially disclosed price range scares off investors and leads to cancellations and scaling down of orders. $73 \%$ agreed. The disagreeing $27 \%$ mostly explained that an opposite effect of increased appetite would be more likely, because a higher offer price is indicative of high demand and a large price jump on the first trading day.

The prime determinant of how the final offer price compares to the price range is investors' demand for the shares. We asked whether other factors or considerations have played a role. In most cases (58\%), however, CEOs pointed out that demand was the sole determinant in the final step of the pricing process. Others indicated that differences in the perceived quality of eligible investors across various price levels $(21 \%)$, the desire of a share price increase at the commencement of trading (15\%), 
negotiations with the bank (6\%), the idea that pricing below the midpoint would leave a negative impression (6\%), and recent stock market developments $(3 \%)$ had played a role. (Three CEOs named two of these considerations.)

According to Welch's (1989) signaling hypothesis, there are issuers who strategically leave money on the table in IPOs to entice investors to pay higher prices at future offerings. We asked all CEOs whether they believe that a lower IPO price allows a higher price at a subsequent issue because it leaves a better taste in investors' mouths. A majority of $57 \%$ answered affirmative. The others either think that the effect only happens when the time between IPO and seasoned equity offering (SEO) is short $(11 \%)$, or did not see the relation at all (33\%). In a similar spirit, Brau and Fawcett (2006a) report that their respondents believe that large first-day stock price jumps are positive signals to investors.

We also asked whether the offer price has been influenced by the prospect of a possible follow-on offering. Out of those involved in a fixed price or book-built IPO who believe in a link between IPO and SEO prices, 64\% confirmed that the price has been actually set lower for this reason. Across the entire sample of fixed price and book-built IPOs this corresponds to $37 \%$.

In their presentation, the bankers indicated that a higher price could be feasible, but they took into account that follow-on issues were already planned. The transactions formed an important coherent whole that required satisfied shareholders. Existing shareholders agreed because they would reap the benefits of a favorable stock price development as well.

These results are at odds with earlier, more conventional empirical work on signaling theory that mostly finds little evidence in support of the predicted relation between underpricing and the decision to reissue (Jegadeesh et al. 1993; Michaely and Shaw 1994; Espenlaub and Tonks 1998). Yet, our questions to the CEOs are about the consequences of IPO pricing for the pricing of subsequent equity sales, and only indirectly about the consequences of IPO pricing for the decision to actually conduct a SEO. To the best of our knowledge there exists no conventional empirical study into the former question.

The IPO process normally also includes promotional activities, most notably press releases and road shows in which management presents the company to investors. We asked our respondents whether they believe that a relatively extensive promotional campaign allows a relatively high offer price. A majority of $77 \%$ indicated that they do believe so. A variety of explanations were given, and most frequently these referred to the narrowing of information asymmetries, the raising of awareness about the IPO, or the creation of a positive sentiment or hype.

\subsection{Allocation}

We asked CEOs whether they themselves or their shareholders have exercised substantial influence during this final stage of the IPO process. ${ }^{8}$ We got affirmative answers

\footnotetext{
8 In the Netherlands the IPO market is largely of the private-placement type, where shares are sold to institutional investors and allocation is completely discretionary. Many IPOs also include a retail tranche,
} 
from $52 \%$, and these respondents mostly indicated that the interference with the allocation had been at the individual-investor level. At the same time they also often put their influence into perspective by adding that their role had been subordinate to that of the bank. Another $18 \%$ had not concerned themselves about individual cases, but did put their stamp on the subdivision across broad categories such as institutional versus retail investors or national versus international investors. The remaining $30 \%$ left the allocation to the bank, although some added that they were nevertheless passively involved and did have insight into the order book. In two of these cases a pro rata allocation was used, leaving no room for interference. Assuming that firms prefer long-term investors, the interference of a total of $70 \%$ with the allocation of shares may be part of the explanation for why IPO allocations consistently favor those types of investors (Jenkinson and Jones 2004).

The bank was leading, it's their craft. But we have gone through the lists of subscribers ourselves and interfered with the allocation. Our preferences were driven by impressions about institutional investors that we had formed during the road shows.

Next, we asked the CEOs whether they believe that banks have let their own business interests play a significant part in the allocation by favoring specific investors. A clear majority of $86 \%$ considered this to be the case. Seven CEOs added that they are absolutely sure that this has happened, but at the same time eight CEOs spontaneously explained that they do not object to such practices as long as it is not detrimental to their company. In several interviews the importance of the banks' relationships with their investor clienteles already appeared when we talked about the pricing process. The remaining 14\% did not believe that the bank has privileged specific investors. However, in most of these cases preferential treatments were simply not possible, either because of pro rata allocation or because of undersubscription.

The bank has a continuing relationship with these clients. As a bank you want to keep friendly with most of them, for they might eventually come up with profitable transactions.

In advance of the whole process they have already visited their clients and promised a considerable price increase. That discount needs to be implemented, otherwise the bank has a problem.

This result reinforces the survey evidence of Jenkinson and Jones (2009a) that IPO allocations are a quid pro quo for brokerage business in the first place. According to Jenkinson and Jones, institutional investors who regularly participate in IPOs perceive the extent of brokerage business with the investment banks to be the most important factor to receiving a favorable allocation.

Footnote 8 continued

which typically represents only a small fraction of the offering. Retail shares are allocated on a "fair" basis, where all investors who subscribed for the same number of shares are treated similarly. 


\subsection{Private Equity and Venture Capital}

Twenty-six firms in our sample had one or more private equity or venture capital (henceforth collectively referred to as VC) firms in their shareholder base prior to the IPO. We asked the CEOs of those firms whether they had somehow already committed themselves to an IPO because of an agreement with these investors long before the firm actually went public. In $35 \%$ of the cases, an IPO had indeed explicitly been on the horizon, with most agreements being informal in nature. In the remaining $65 \%$ there was no such plan. Nevertheless, about half of the times these respondents added that an IPO had always been considered as a serious exit opportunity or a way to raise additional capital.

VC firms are often appreciated for actively supporting the companies in which they invest. In only 19\% of the VC-backed IPOs, however, VC firms are credited for an active contribution to preparations or transformations targeted at the IPO. The specific forms of active support that CEOs mentioned are related to corporate strategy, to the implementation of acquisitions, and to corporate governance. The remaining $81 \%$ denied that they have been actively supported by VCs in their run-up to the IPO. About $40 \%$ of this group added that they believe that their firm was already IPO-ready when these investors became a shareholder.

About half (46\%) of the CEOs of VC-backed IPOs indicated that their VCs have played a significant role in the pricing process. Their VC firms negotiated directly with the bank, imposed a minimum price in advance, or were repeatedly consulted during the negotiations. In the other half of the cases (54\%), the role of VCs was limited to (at most) giving approval. Among the subset of IPOs where VC firms directly or indirectly participated in the negotiations, $40 \%$ of the CEOs believed that VC involvement has led to a higher offer price.

In 23 cases at least one pre-IPO VC firm retained a portion of its holding after the IPO. We asked the CEOs of those firms whether there have been talks with these shareholders during the IPO process about their intentions after the expiration of a possible lock-up arrangement. 40\% answered affirmatively. Mostly (63\%), the VC firm had then expressed its intention to hold on to its stake. The remaining $60 \%$ said that there had not been such talks.

According to the certification (Megginson and Weiss 1991) and screening and monitoring (Barry et al. 1990) hypotheses for VC-backed IPOs, the offer price would be positively affected by the presence of VCs in an issuing firm's shareholder base. In this light, we asked all CEOs whether they believe that the presence of a VC firm has a positive influence on investors' trust in the company at the time of the IPO. Out of the CEOs who had dealt with at least one VC shareholder prior to the IPO, $76 \%$ considered this to be true. About half of them voluntarily explained that the presence of such a shareholder signals quality or professionalism, and about one-third added that the positive influence especially or exclusively holds for reputable VCs. The remaining $24 \%$ believed that there is no such influence or claimed that the relation is negative because the (intended) exit of a well-informed investor signals overvaluation. Not surprisingly, CEOs who did not deal with VC prior to the IPO were less positive about the effect on investors' trust: $44(56) \%$ believed that there is a positive (no or a negative) influence. The arguments they brought forward are similar to those of 
CEOs with pre-IPO VC experiences. We also asked those who answered affirmatively whether they have seriously considered approaching a VC firm to take a stake in the company for this reason. Only one (13\%) had done so.

\section{IPO Success}

How do CEOs look back at the IPO and the resulting changes for the firm? At the end of each interview we talked about the success of the IPO from the perspective of the firm. To examine the evaluation and determinants of IPO success we used three different questions. First, we asked CEOs to express their view on the overall success of the IPO on a five-point Likert scale running from "very poor" (1) to "very good" (5). Second, we asked them to name the most important factors that are driving this overall score. Last, we presented a scheme with thirteen pre-identified aspects and possible implications of the IPO, and requested the CEOs to evaluate these different factors on the five-point scale used before. To mitigate possible effects of differences in the number of years between the IPO and the interview, we asked them to base their overall and individual factor ratings on the first 2 years after the listing.

Below, we first present the overall success scores and the categories of determinants that CEOs formulated themselves. Next, we explain the thirteen pre-identified factors that we used and we summarize the scores for each of these factors. In the final subsection we analyze how overall success depends on the pre-identified factors.

\subsection{IPO Success and Important Success Factors}

Panel A of Table 6 summarizes the overall IPO success ratings. A total of $83 \%$ of the CEOs assessed the success of the IPO as "good" (39\%) or "very good" (43\%). The mean of the overall scores is $4.09 .{ }^{9}$ If overall IPO success can be interpreted as the net benefits of flotation, then this result is similar to the IPO evaluations of the seven U.K. executives interviewed in Burton et al. (2006) and the questionnaire results in Bancel and Mittoo (2009).

Panel B of Table 6 presents our categorization of the factors that CEOs tabled as being important for their overall success rating. On average, they cited factors from two different categories. About half of them (48\%) mentioned the new financing opportunities and pointed at the immediate proceeds from the IPO or the opportunity to issue equity at a later stage. About one-third (38\%) referred to changes in visibility or perceptions of the credibility of the firm in general, and approximately one in four $(23 \%)$ specifically cited changes in confidence among customers or suppliers, or changes in relations with these stakeholders. These three success factors are also frequent reasons for why companies go public (Baker and Johnson 1990; Ravasi and Marchisio 2003; Brau and Fawcett 2006a; Burton et al. 2006; Bancel and Mittoo $2009,2014)$. One in three $(35 \%)$ emphasized effects on staffing, and one in four (25\%) mentioned a factor related to the performance or liquidity of the stock.

\footnotetext{
9 Note that both the average overall success score and the average success factor scores may be inflated, because the likelihood of participation in our survey is possibly related to the success of the IPO and to how well the firm fared afterwards.
} 
Table 6 Overall IPO success and important success factors

\begin{tabular}{|c|c|c|c|}
\hline \multicolumn{2}{|l|}{ Panel A: Overall success rating } & \multirow{2}{*}{$\frac{\text { Nos. }}{18}$} & \multirow{2}{*}{$\frac{\%}{39.1}$} \\
\hline Very good & & & \\
\hline Good & & 20 & 43.5 \\
\hline Neither good, nor poor & & 3 & 6.5 \\
\hline Poor & & 4 & 8.7 \\
\hline Very poor & & 1 & 2.2 \\
\hline Panel B: Important success factors & Nos. & $\%$ raw & $\%$ adj \\
\hline $\begin{array}{l}\text { Access to equity finance (IPO, SEOs, stock as } \\
\text { acquisition currency) }\end{array}$ & 19 & 47.5 & 28.8 \\
\hline Changes in visibility and credibility in general & 15 & 37.5 & 15.8 \\
\hline $\begin{array}{l}\text { Changes in confidence of/relations with customers and } \\
\text { suppliers }\end{array}$ & 9 & 22.5 & 9.8 \\
\hline $\begin{array}{l}\text { Effects on staffing: involvement, retention and } \\
\text { recruitment }\end{array}$ & 14 & 35.0 & 15.6 \\
\hline $\begin{array}{l}\text { Changes in quality and functioning of organization and } \\
\text { management }\end{array}$ & 9 & 22.5 & 10.4 \\
\hline Stock price performance and liquidity & 10 & 25.0 & 15.8 \\
\hline Quality and costs of investor relations & 3 & 7.5 & 3.8 \\
\hline
\end{tabular}

The table gives an overview of the responses when we asked CEOs how they evaluated the overall success of the IPO for their firm after 2 years of listing on a five-point scale running from very poor to very good (Panel A; $N=46$ ), and when we asked through an open-ended question for the factors that they believe are important in this evaluation (Panel B; $N=40$ ). The columns of Panel B are defined as in Table 2

\subsection{Pre-identified Success Factors and Background}

Our list of pre-specified success factors has been inspired by prior theoretical and empirical work. Four factors on the list are related to share price performance and liquidity, nine to corporate and managerial changes. Below, we provide background to explain our considerations for including the various factors.

Stock Price Performance on the First Trading Day The first-day return accrues to the new shareholders, and represents an opportunity cost to the firm's pre-issue shareholders (Zingales 1995). At the same time, an unexpectedly high market price reflects good news for existing shareholders who did not sell or sold only a part of their stake (Loughran and Ritter 2002). Also, a large first-day price jump can be seen as a positive signal that improves the feasibility and conditions of future equity issues (Welch 1989; Allen and Faulhaber 1989; Chemmanur 1993; Brau and Fawcett 2006a). Last, the initial return often receives media attention and may be seen by outsiders as an indicator of how the firm and its prospects are perceived by the market. 
Stock Price Performance Over the First 2 Years The performance of the stock price is indicative of the performance and outlook of the firm and the satisfaction of shareholders. High longer-term returns can be interpreted as positive feedback from the market, and may also enhance the firm's ability or willingness to use stock as a currency for acquisitions.

Stock Price Stability Over the First 2 Years Subrahmanyam and Titman (2001) examine why day-to-day changes in stock prices are a concern to managers, and find that they impact the cash flows of a firm through effects on the decisions of customers, suppliers, employees and other non-investor stakeholders. Hsieh et al. (2011) argue that valuation uncertainty leads to suboptimal decision making, particularly in merger and acquisition transactions.

Liquidity of the Shares Over the First 2 Years Liquidity is an important determinant of transaction costs. If investors factor in expected transaction costs, firms benefit from better liquidity through a decrease in the cost of capital (Amihud and Mendelson 1986, 1988; Becker-Blease and Paul 2006). Active trading in the shares may also enhance the precision of the share price as a signal of the company's value and thereby facilitate equity and debt issues (Röell 1996).

Changes in Ability to Issue Equity for Financing Investments/Acquisitions An IPO improves the firm's opportunities to issue new equity at a later stage, as it creates liquidity for the shares and resolves valuation uncertainty. The post-IPO acquisition activities of newly listed firms underline the potential relevance of this factor (Celikyurt et al. 2010).

Changes in Media Attention and Visibility Most IPOs generate substantial publicity, and listed companies can expect to receive more media attention than they did before. Attention and visibility may impact both the operations and the valuation of the company.

Changes in Business Relationships: Credibility and Reputation With an IPO, firms commit themselves to satisfying the listing requirements imposed by the stock exchange, and the new regime of reporting and corporate governance standards can be expected to reduce potential information asymmetries and moral hazard risks.

Changes of Organizational and Strategic Nature An IPO can improve a firm's competitive position. Firms can use the IPO proceeds and capital market access for strategic acquisitions and to compete more aggressively (Maksimovic and Pichler 2001; Schultz and Zaman 2001; Chod and Lyandres 2011; De Jong et al. 2012). Also, a firm's organizational structure may benefit from the preparations of the IPO, and from the disciplinary role of reporting requirements, governance standards and visibility after the IPO (Burton et al. 2004; von Eije et al. 2004).

Changes in Bank Relationships: Borrowing Terms/Bargaining Power Pagano et al. (1996, 1998) show that Italian firms borrow more cheaply after an IPO. Possible 
explanations are the lower information costs of lenders and the greater bargaining power of firms: the increased availability of information makes it less costly for a bank to assess a firm's creditworthiness, and the increased availability of outside financing options gives the firm more bargaining power (Rajan 1992; Bancel and Mittoo 2009).

Changes in Staffing: Retention and Recruitment An IPO can increase the attractiveness of a firm as a potential employer and the morale of existing employees in various ways. The status as a listed firm may enhance its visibility and reputation in the labor market, the improved access to external financing allows more investments in human capital, and the listing facilitates the implementation of employee stock ownership and option plans. Borisov et al. (2015) find that firms display higher employment growth after their IPO than before (see also Kenney et al. 2012).

Changes in Reporting Requirements and Transparency Firms going public are required to provide extensive information in their prospectus and to meet continuing disclosure standards afterwards. These requirements entail administrative costs and may weaken the firm's competitive position within its industry (Yosha 1995; Maksimovic and Pichler 2001).

Changes in Pressure from Shareholders Going public involves new external shareholders who will scrutinize the performance of the firm and its management. Analysts and other market participants may also start critically evaluating the firm's operations and results.

Changes in Management Involvement in Investor Relations Activities Investor relations activities include the organization of shareholder meetings, analyst meetings and press conferences, the maintenance of an investor relation section on the company's website, and handling inquiries (Brennan and Tamarowski 2000; Bushee and Miller 2012; Agarwal et al. 2016). Hong and Huang (2005) estimate that for small and newlypublic firms investor relations activities take $20-25 \%$ of the CEO's time and about $50 \%$ of the CFO's time.

Our list of pre-identified success factors appeared to be sufficiently exhaustive. After we showed our respondents the list, we asked them whether they believe that the list is complete and invited them to name additional factors. Only three CEOs proposed a factor, but in all three cases these factors were already more broadly represented by one of the factors on our list.

Table 7 lists the thirteen success factors and shows how the average respondent evaluated these on the five-point Likert scale running from 1 ("very poor") to 5 ("very good"). To calculate the means, we treated the responses as interval data. The scores for the four factors related to share price performance and liquidity are relatively close to neutral, whereas those for most of the nine related to corporate and managerial changes are somewhat higher. The worst score pertains to the liquidity of the firm's shares (2.6), the best to changes in credibility and reputation (3.9) and changes in staffing (3.9). Note that all thirteen averages are lower than the average overall success rating of 4.1 . 


\subsection{Regression Analyses and Results}

We now turn to regression analysis to assess how overall success depends on the thirteen factors. Because overall success is measured on an ordinal scale we use the ordered probit model (Greene and Hensher 2010). The coefficients are estimated with threshold parameters set by maximum likelihood estimation using the $\mathrm{BHHH}$-algorithm (which is also possible with ordinal regressors). In order to improve efficiency and reduce bias, we assign real values to the ordinal latent explanatory variables by transforming the scores using Terza's (1987) method. ${ }^{10}$

The third column of Table 7 shows the coefficients and $p$-values for univariate regressions. As expected, all coefficients are positive. Four factors are statistically significant determinants at the $1 \%$ level: stock price performance, stock price stability, changes in staffing, and changes in media attention and visibility. Three more are significant at the 5\% level: changes in credibility and reputation, changes of organizational and strategic nature, and changes in management involvement in investor relations activities. A limitation of the univariate tests is, of course, that they ignore the dependencies between the different factors. We therefore also conduct multivariate regressions.

The fourth column of Table 7 shows the results for the most comprehensive multivariate specification (Model 1). When all factors are included, all individual coefficients are statistically insignificant at the 5\% level. This null result is, however, not very surprising in the light of the correlations between the variables and the relatively small sample size. We therefore also consider specifications that include a subset of the regressors only. Starting from the full multivariate model, and informed by the univariate results and the correlation structure, we identify two models that produce the best empirical fit given the number of included variables. As shown in the last two columns, these two models yield a similar statistical fit. ${ }^{11}$

Both regression models confirm the importance of stock price performance and changes in media attention and visibility. Note that these factors were also frequently cited in response to our open-ended question about the critical success factors (Table 6, Panel B). The importance of the longer-term return of shareholders is not very surprising, because this factor reflects changes in the wellbeing of the firm and the satisfaction of shareholders. The importance of how the IPO and listing have put the firm in the spotlight is consistent with studies into the reasons for going public citing increasing visibility as a key reason (Baker and Johnson 1990; Ravasi and Marchisio 2003; Burton et al. 2006; Bancel and Mittoo 2009).

In addition, one of the two models also emphasizes the role of changes in staffing (Model 2), whereas the alternative specification instead also emphasizes the role of changes in management involvement in investor relations activities (Model 3). Includ-

\footnotetext{
10 We find similar results when we replace the transformed regressors by integer values ranging from 1 ("very poor") to 5 ("very good"), and when we replace the ordered probit approach by ordinary least squares.

11 In Model 2, we set the two missing values for the factor "changes in staffing" equal to zero and we include a dummy variable for the two specific respondents (suppressed in the table). If we instead leave out all observations from those two respondents, the three coefficients remain significant at the $5 \%$ level but the pseudo $R^{2}$ drops from 0.250 to 0.218 .
} 
Table 7 Success factor scores and ordered probit regression results

\begin{tabular}{|c|c|c|c|c|c|}
\hline & \multirow[t]{2}{*}{ Mean score } & \multirow[t]{2}{*}{ Univariate } & \multicolumn{3}{|c|}{ Multivariate } \\
\hline & & & Model 1 & Model 2 & Model 3 \\
\hline $\begin{array}{l}\text { Stock price performance on the } \\
\text { first trading day }(N=45)\end{array}$ & 3.62 & $\begin{array}{l}0.084 \\
\quad(0.653)\end{array}$ & $\begin{array}{r}-0.155 \\
(0.559)\end{array}$ & & \\
\hline $\begin{array}{l}\text { Stock price performance over the } \\
\text { first } 2 \text { years }(N=46)\end{array}$ & 3.17 & $\begin{array}{l}0.600 \\
\quad(0.001)\end{array}$ & $\begin{array}{l}1.069 \\
(0.058)\end{array}$ & $\begin{array}{l}0.478 \\
\quad(0.039)\end{array}$ & $\begin{array}{l}0.589 \\
\quad(0.005)\end{array}$ \\
\hline $\begin{array}{l}\text { Stock price stability over the first } \\
2 \text { years }(N=46)\end{array}$ & 2.98 & $\begin{array}{l}0.552 \\
\quad(0.001)\end{array}$ & $\begin{array}{r}-0.556 \\
(0.283)\end{array}$ & & \\
\hline $\begin{array}{l}\text { Liquidity of the shares over the } \\
\text { first } 2 \text { years }(N=45)\end{array}$ & 2.64 & $\begin{array}{l}0.175 \\
\quad(0.356)\end{array}$ & $\begin{array}{r}-0.308 \\
(0.366)\end{array}$ & & \\
\hline $\begin{array}{l}\text { Changes in ability to issue equity } \\
\text { for financing } \\
\text { investments/acquisitions } \\
(N=37)\end{array}$ & 3.57 & $\begin{array}{l}0.300 \\
\quad(0.293)\end{array}$ & $\begin{array}{r}-0.268 \\
(0.569)\end{array}$ & & \\
\hline $\begin{array}{l}\text { Changes in media attention and } \\
\text { visibility }(N=46)\end{array}$ & 3.85 & $\begin{array}{l}0.631 \\
\quad(0.010)\end{array}$ & $\begin{array}{l}0.793 \\
\quad(0.080)\end{array}$ & $\begin{array}{l}0.514 \\
\quad(0.009)\end{array}$ & $\begin{array}{l}0.639 \\
\quad(0.002)\end{array}$ \\
\hline $\begin{array}{l}\text { Changes in business } \\
\text { relationships: credibility and } \\
\text { reputation }(N=42)\end{array}$ & 3.88 & $\begin{array}{l}0.457 \\
\quad(0.034)\end{array}$ & $\begin{array}{l}0.078 \\
\quad(0.850)\end{array}$ & & \\
\hline $\begin{array}{l}\text { Changes of organizational and } \\
\text { strategic nature }(N=39)\end{array}$ & 3.62 & $\begin{array}{l}0.461 \\
\quad(0.047)\end{array}$ & $\begin{array}{l}0.361 \\
\quad(0.297)\end{array}$ & & \\
\hline $\begin{array}{l}\text { Changes in bank relationships: } \\
\text { borrowing terms/bargaining } \\
\text { power }(N=37)\end{array}$ & 3.68 & $\begin{array}{l}0.228 \\
\quad(0.363)\end{array}$ & $\begin{array}{l}0.252 \\
\quad(0.531)\end{array}$ & & \\
\hline $\begin{array}{l}\text { Changes in staffing: retention and } \\
\text { recruitment }(N=44)\end{array}$ & 3.91 & $\begin{array}{l}0.715 \\
\quad(0.001)\end{array}$ & $\begin{array}{l}0.557 \\
\quad(0.101)\end{array}$ & $\begin{array}{l}0.533 \\
\quad(0.048)\end{array}$ & \\
\hline $\begin{array}{l}\text { Changes in reporting } \\
\text { requirements and transparency } \\
(N=43)\end{array}$ & 3.70 & $\begin{array}{l}0.218 \\
\quad(0.306)\end{array}$ & $\begin{array}{r}-0.103 \\
(0.736)\end{array}$ & & \\
\hline $\begin{array}{l}\text { Changes in pressure from } \\
\text { shareholders }(N=46)\end{array}$ & 3.28 & $\begin{array}{l}0.238 \\
\quad(0.180)\end{array}$ & $\begin{array}{r}-0.115 \\
\quad(0.680)\end{array}$ & & \\
\hline $\begin{array}{l}\text { Changes in management } \\
\text { involvement in investor } \\
\text { relations activities }(N=46)\end{array}$ & 3.11 & $\begin{array}{l}0.401 \\
\quad(0.035)\end{array}$ & $\begin{array}{l}0.492 \\
\quad(0.144)\end{array}$ & & $\begin{array}{l}0.402 \\
\quad(0.032)\end{array}$ \\
\hline Pseudo $R^{2}$ & & & 0.329 & 0.250 & 0.222 \\
\hline
\end{tabular}

The table displays the average evaluation scores that CEOs assigned to thirteen predefined potential success factors, and the results from ordered probit regression analyses for their overall IPO success scores. To obtain the factor scores, we asked each CEO to evaluate the various aspects and possible implications of the IPO from the perspective of the firm on a five-point Likert scale (very poor, poor, neither poor not good, good, very good). The first column lists the various factors, the second column gives the mean evaluation score for each factor, and the other four columns present the regression coefficients ( $p$-values in parentheses). To calculate the mean scores, we treated the responses as interval data (very poor $=1, \cdots$, very good $=5$ ). In the regressions, we assigned real values to the ordinal latent explanatory variables by transforming the responses (very poor $=1, \cdots$, very good $=5$ ) on the basis of Terza's $(1987)$ method

ing both factors jointly in combination with the other two renders their coefficients insignificant and does not materially improve the fit of the model. Unlike the effect on staffing and the two factors that appear in both models, investor relations changes were only sporadically mentioned in response to our open question (Table 6, Panel B). 
We therefore believe that the model that includes changes in staffing (Model 2) is the most representative model of the factors driving the evaluation of overall IPO success. The conclusion that the effect of the IPO on staffing is among the key determinants of IPO success underlines the important role of human capital for firms' operations, and suggests that the positive impact of the IPO in this domain is often unexpected.

Note that the most frequently cited category of critical factors in Table 6 encompasses the pre-identified factor "changes in ability to issue equity", whereas this factor turns out to be insignificant in both the univariate and the multivariate specifications. A possible explanation is that this change was important but also anticipated.

Last, we have compared CEOs' subjective assessments of the four stock-market related success factors with objective measurements of what has actually happened with respect to those factors. Their evaluations align with the market data, in the sense that a higher success-factor score is generally confirmed by a more favorable market statistic for the given item. ${ }^{12}$ Also, when we estimate alternative specifications of the regression models where we replace the subjective assessments of the four stockmarket related success factors by their objective counterparts, the results confirm that IPO success is primarily driven by how well the firm fared in terms of stock price performance, changes in media attention and visibility, and changes related to the retention and recruitment of staff.

\section{Conclusions}

Based on 46 interviews with key executives involved in an IPO in the Netherlands we have examined a variety of aspects of the process and success of going public from a managerial perspective. Measured from lead manager selection until listing, the average IPO process lasts 6-7 months. The process is always (co-)directed by one or more executive directors of the issuing firm, while external shareholders mostly take a passive role.

Lead managers are primarily selected because of relational and expertise-related aspects. Relatively unimportant selection criteria are fees and valuation indications. Preferences for other syndicate members are predominantly driven by their investor client base and by pre-existing relationships.

CEOs are generally aware of potential conflicts of interest with the lead manager during the pricing process. Issuing firms are actively involved in "desk" valuations, and about half of the time they ask an external party or syndicate member for their view. At the same time, many CEOs point at their own agency dilemma and acknowledge that they were not inclined to get the maximum out of the IPO for pre-IPO shareholders because they wanted to satisfy new shareholders as well.

\footnotetext{
12 Using market data from Datastream, we calculated the return on the first trading day, the return of the stock over the 2 years after the first trading day, the standard deviation of the stock's daily returns over these 2 years, and the average daily turnover as a percentage of the number of shares outstanding over these 2 years. The Spearman rank-order correlations between the subjective assessments and their objective counterparts all have the expected sign and are statistically significant (liquidity at the 10\% level, the other three at the $1 \%$ level).
} 
We find support for strategic underpricing. More than half of the CEOs believe that a lower IPO price allows a higher price at a subsequent equity issue because it leaves a better taste in investors' mouths. Two thirds of this subgroup confirm that the offer price has actually been set lower for this reason.

Pre-marketing plays an important role throughout the pricing process and frequently drives changes in the expected offer price. In book-built IPOs, the width of the price range is especially driven by uncertainty about the value of the shares. Even though IPOs are rarely priced above the upper bound of the range, about half of the CEOs think that the lead manager would have been prepared to do so.

Most issuing firms are involved in determining the allocation policy, but their role is subordinate to that of the lead manager. A clear majority of the CEOs believe that the lead manager's business interests have had a strong influence on the allocation.

Most CEOs believe that the presence of a VC firm in the shareholder base has a positive influence on investors' trust in the company. Only about half of the times VC firms play a significant role in the pricing process of VC-backed IPOs.

Our final set of main findings relate to how CEOs evaluate the success of the IPO. On a scale running from one to five their average rating is 4.1. Regardless of whether we ask CEOs directly for the critical success factors or whether we more indirectly first ask them to evaluate a list of pre-specified factors and then regress their overall success ratings on the ratings for these factors, managerial perceptions of IPO success are especially determined by how well the firm has fared in terms of stock price performance, changes in media attention and visibility, and changes related to the retention and recruitment of staff.

Open Access This article is distributed under the terms of the Creative Commons Attribution 4.0 International License (http://creativecommons.org/licenses/by/4.0/), which permits unrestricted use, distribution, and reproduction in any medium, provided you give appropriate credit to the original author(s) and the source, provide a link to the Creative Commons license, and indicate if changes were made.

\section{Appendix: Overview of Questions and Numbers of Respondents}

See Table 8 .

Table 8 Questions and numbers of respondents

Question

Respondents, missing, not applicable

1. What was your role in the IPO process?

$46,0,0$

2. How many months were there between the selection of the lead manager and

$45,1,0$ the first trading day?

3. Who had the lead role in directing the IPO process on behalf of the issuing

$46,0,0$ firm and its shareholders?

4. How did the selection of the lead manager happen?

$44,2,0$ 
Table 8 continued

Question

Respondents,

missing, not applicable

5. What have been the most important considerations in the lead manager choice?

$46,0,0$

6. Do you think the name or reputation of the lead manager has an influence on the offer price?

7. Did you negotiate on the percentage fee that was to be paid to the lead manager and other syndicate members?

8. Did you exert influence on the composition of the syndicate?

$41,5,0$

9. What have been your most important considerations in proposing or

$36,1,9$ selecting syndicate members?

10. Have you discussed the pricing of the shares with the lead manager before the lead manager was formally hired?

11. Who has carried out the desk valuation(s) of the firm?

$33,0,13$

$43,3,0$

$46,0,0$

12. When has the offer price (fixed price IPOs) or price range (book-built IPOs) — as disclosed in the (preliminary) prospectus - been established?

13. Which factors have led to changes in the expected offer price (fixed-price IPOs) or price range level (book-built IPOs) throughout the pricing process?

14. Which factors have affected the width of the price range?

$40,4,2$

$42,2,2$

$32,3,11$

15. Did you negotiate on the pricing of the shares with the lead manager?

$43,1,2$

Please express the intensity of negotiations on the following five-point scale: no, moderate, medium, considerable, strong.

16. With the benefit of hindsight, do you wish you had negotiated (even) stronger on pricing?

17. Were there any potential conflicts of interest between your firm and the lead manager throughout the pricing process?

18. Would you have gone along with an offer price below the initial price range if the bank had proposed to do this?

19. Do you believe the bank would have been prepared to set the offer price above the initial price range if investor demand would have given rise to it?

20. Do you agree or disagree with the statement that setting the price above the initially disclosed price range scares off investors and leads to cancellations and scaling down of orders?

21. Which factors other than investors' demand have determined how the final offer price ultimately compared to the initial price range?

22. Do you believe that a lower IPO price allows a higher price at a subsequent issue, because a lower price leaves a better taste in investors' mouths?

23. Has the offer price been set relatively low because of the prospect of a possible follow-on offering?

24. Do you believe that a relatively extensive promotional campaign allows a relatively high offer price?

25. Did you or your shareholders exercise substantial influence on the allocation of the shares? 
Table 8 continued

Question

Respondents, missing, not applicable

26. Do you believe that the bank has let its own business play a significant part $44,0,2$ in the allocation by favoring specific investors?

27. Was your firm somehow already committed to a future IPO because of an agreement with one or more of your pre-IPO private equity or venture capital shareholders long before it actually went public?

28. Was any of your pre-IPO private equity or venture capital shareholders directly involved in preparing or transforming your firm for the IPO, ahead of the actual IPO process?

29. Did any of your pre-IPO private equity or venture capital shareholders play a significant role in the pricing process?

30. Do you believe that the significant role of one or more of your private equity or venture capital firms in the pricing process has led to a higher offer price?

31 . Have you talked with any of your private equity or venture capital shareholders about their intentions regarding their shareholdings after the IPO and the expiration of a possible lock-up period?

32. Do you believe that the presence of a private equity or venture capital firm as a shareholder increases investors' trust in the company at the time of the IPO?

33. Have you considered attracting a venture capital or private equity firm prior to the IPO to increases investors' trust in the company?

34. How did you evaluate the success of the IPO after 2 years of listing on the following five-point scale: very poor, poor, neither poor nor good, good, very good? Please answer from the perspective of the firm.

35. What factors are important in your evaluation of the success of the IPO as measured after 2 years of listing?

36. Please take a look at this scheme. Please indicate how you evaluate the thirteen different aspects and possible implications of the IPO on the five-point scale that ranges from very poor to very good. Please answer from the perspective of the firm.

The table presents the uniform set of questions that we used in the 46 interviews with CEOs and CFOs who were closely involved in an Initial Public Offering in the Netherlands between 1990 and 2008. For each question, the last column shows the number of responses, the number of interviews where the respondent either could not recollect or where the question was not asked by mistake or due to time pressure, and the number of interviews for which the question was not applicable. The order in which the various topics were discussed was not fixed, but depended on how the conversation unfolded. Whenever relevant or potentially interesting, we asked for more elaborate answers or went deeper into specifics. The original questions were in Dutch

\section{References}

Abrahamson, M., Jenkinson, T. J., \& Jones, H. (2011). Why don't U.S. issuers demand European fees for IPOs? Journal of Finance, 66(6), 2055-2082.

Agarwal, V., Taffler, R. J., Bellotti, X., \& Nash, E. A. (2016). Investor relations, information asymmetry and market value. Accounting and Business Research, 46(1), 31-50.

Allen, F., \& Faulhaber, G. R. (1989). Signaling by underpricing in the IPO market. Journal of Financial Economics, 23(2), 303-323. 
Amihud, Y., \& Mendelson, H. (1986). Asset pricing and the bid-ask spread. Journal of Financial Economics, 17(2), 223-249.

Amihud, Y., \& Mendelson, H. (1988). Liquidity and asset prices: Financial management implications. Financial Management, 17(1), 5-15.

Baker, H. K., \& Johnson, M. (1990). A survey of management views on exchange listing. Quarterly Journal of Business and Economics, 29(4), 3-20.

Bancel, F., \& Mittoo, U. R. (2009). Why do European firms go public? European Financial Management, 15(4), 844-884.

Bancel, F., \& Mittoo, U. R. (2014). The gap between the theory and practice of corporate valuation: Survey of European experts. Journal of Applied Corporate Finance, 26(4), 106-117.

Barry, C. B., Muscarella, C. J., Peavy, J. W, I. I. I., \& Vetsuypens, M. R. (1990). The role of venture capital in the creation of public companies: Evidence from the going public process. Journal of Financial Economics, 27(2), 447-471.

Becker-Blease, J. R., \& Paul, D. L. (2006). Stock liquidity and investment opportunities: Evidence from index additions. Financial Management, 35(3), 35-51.

Borisov, A., Andrew, E., \& Merih, S. (2015). Access to public capital markets and employment growth. Working paper. http://ssrn.com/abstract $=2178101$.

Brau, J. C., \& Fawcett, S. E. (2006a). Initial public offerings: An analysis of theory and practice. Journal of Finance, 61(1), 399-436.

Brau, J. C., \& Fawcett, S. E. (2006b). Evidence on what CFOs think about the IPO process: Practice, theory, and managerial implications. Journal of Applied Corporate Finance, 18(3), 107-117.

Brau, J. C., Ryan, P. A., \& DeGraw, I. (2006). Initial public offerings: CFO perceptions. Financial Review, 41(4), 483-511.

Brennan, M. J., \& Tamarowski, C. (2000). Investor relations, liquidity, and stock prices. Journal of Applied Corporate Finance, 12(4), 26-37.

Burton, B. M., Helliar, C. V., \& Power, D. M. (2004). The role of corporate governance in the IPO process: A note. Corporate Governance: An International Review, 12(3), 353-360.

Burton, B. M., Helliar, C. V., \& Power, D. M. (2006). Practitioners' perspectives on the IPO process and the perils of flotation. European Journal of Finance, 12(8), 671-692.

Bushee, B. J., \& Miller, G. S. (2012). Investor relations, firm visibility, and investor following. Accounting Review, 87(3), 867-897.

Celikyurt, U., Sevilir, M., \& Shivdasani, A. (2010). Going public to acquire? The acquisition motive in IPOs. Journal of Financial Economics, 96(3), 345-363.

Chemmanur, T. J. (1993). The production of initial public offerings: A dynamic model with information production. Journal of Finance, 48(1), 285-304.

Chod, J., \& Lyandres, E. (2011). Strategic IPOs and product market competition. Journal of Financial Economics, 100(1), 45-67.

Cooney, J. W., Madureirab, L., Singh, A. K., \& Yang, K. (2015). Social ties and IPO outcomes. Journal of Corporate Finance, 33, 129-146.

Corwin, S. A., \& Schulz, P. (2005). The role of IPO underwriting syndicates: Pricing, information production, and underwriter competition. Journal of Finance, 60(1), 443-486.

De Jong, A., Huijgen, C. A., Marra, T. A., \& Roosenboom, P. (2012). Why do firms go public? The role of the product market. Journal of Business Finance and Accounting, 39(1-2), 165-192.

Espenlaub, S., \& Tonks, I. (1998). Post-IPO directors' sales and reissuing activity: An empirical test of IPO signalling models. Journal of Business Finance \& Accounting, 25(9), 1037-1079.

Fernando, C. S., Gatchev, V. A., \& Spindt, P. A. (2005). Wanna dance? How firms and underwriters choose each other. Journal of Finance, 60(5), 2437-2469.

Francis, B. B., Hasan, I., Lothian, J. R., \& Sun, X. (2010). The signaling hypothesis revisited: Evidence from foreign IPOs. Journal of Financial and Quantitative Analysis, 45(1), 81-106.

Gao, X., Ritter, J. R., \& Zhu, Z. (2013). Where have all the IPOs gone? Journal of Financial and Quantitative Analysis, 48(6), 1663-1692.

Greene, W. H., \& Hensher, D. A. (2010). Modeling ordered choices: A primer. Cambridge: Cambridge University Press.

Hong, H., \& Huang, M. (2005). Talking up liquidity: Insider trading and investor relations. Journal of Financial Intermediation, 14(1), 1-31.

Hsieh, J., Lyandres, E., \& Zhdanov, A. (2011). A theory of merger-driven IPOs. Journal of Financial and Quantitative Analysis, 46(5), 1367-1405. 
Jegadeesh, N., Weinstein, M., \& Welch, I. (1993). An empirical investigation of IPO returns and subsequent equity offerings. Journal of Financial Economics, 34(2), 153-175.

Jenkinson, T. J., \& Jones, H. (2004). Bids and allocations in European IPO bookbuilding. Journal of Finance, 59(5), 2309-2338.

Jenkinson, T. J., \& Jones, H. (2009a). IPO pricing and allocation: A survey of the views of institutional investors. Review of Financial Studies, 22(4), 1477-1504.

Jenkinson, T. J., \& Jones, H. (2009b). Competitive IPOs. European Financial Management, 15(4), 733-756.

Jenkinson, T. J., \& Ljungqvist, A. P. (2001). Going public: The theory and evidence on how companies raise equity finance (2nd ed.). Oxford: Oxford University Press.

Jenkinson, T. J., Morrison, A. D., \& Wilhelm, W. J. (2006). Why are European IPOs so rarely priced outside the indicative price range? Journal of Financial Economics, 80(1), 185-209.

Kenney, M., Donald, P., \& Ritter, J. R. (2012). Post-IPO employment and revenue growth for U.S. IPOs, June 1996-2010. Kauffman Foundation Report. http://ssrn.com/abstract=2063829.

Kim, W., \& Weisbach, M. S. (2008). Motivations for public equity offers: An international perspective. Journal of Financial Economics, 87(2), 281-307.

Krigman, L., Shaw, W. H., \& Womack, K. L. (2001). Why do firms switch underwriters? Journal of Financial Economics, 60(2-3), 245-284.

Lowry, M., Officer, M. S., \& William Schwert, G. (2010). The variability of IPO initial returns. Journal of Finance, 65(2), 425-465.

Lowry, M., \& William Schwert, G. (2004). Is the IPO pricing process efficient? Journal of Financial Economics, 71(1), 3-26.

Loughran, T., \& Ritter, J. R. (2002). Why don't issuers get upset about leaving money on the table in IPOs? Review of Financial Studies, 15(2), 413-443.

Maksimovic, V., \& Pichler, P. (2001). Technological innovation and initial public offerings. Review of Financial Studies, 14(2), 459-494.

Megginson, W. L., \& Weiss, K. A. (1991). Venture capitalist certification in initial public offerings. Journal of Finance, 46(3), 879-903.

Michaely, R., \& Shaw, W. H. (1994). The pricing of initial public offerings: Tests of adverse-selection and signaling theories. Review of Financial Studies, 7(2), 279-319.

Pagano, M., Panetta, F., \& Zingales, L. (1996). The stock market as a source of capital: Some lessons from initial public offerings in Italy. European Economic Review, 40(3-5), 1057-1069.

Pagano, M., Panetta, F., \& Zingales, L. (1998). Why do companies go public? An empirical analysis. Journal of Finance, 53(1), 27-64.

Rajan, R. G. (1992). Insiders and outsiders: The choice between informed and arm's-length debt. Journal of Finance, 47(4), 1367-1400.

Ravasi, D., \& Marchisio, G. (2003). Going public and the enrichment of a supportive network. Small Business Economics, 21(4), 381-395.

Ritter, J. R. (2003a). Investment banking and securities issuance. In G. M. Constantinides, M. Harris, \& R. M. Stulz (Eds.), Handbook of the economics of finance (Vol. 1, pp. 255-306). Amsterdam: Elsevier.

Ritter, J. R. (2003b). Differences between European and American IPO markets. European Financial Management, 9(4), 421-434.

Ritter, J. R., \& Welch, I. (2002). A review of IPO activity, pricing, and allocations. Journal of Finance, 57(4), 1795-1828.

Röell, A. (1996). The decision to go public: An overview. European Economic Review, 40(3-5), 1071-1081.

Schenone, C. (2004). The effect of banking relationships on the firm's IPO underpricing. Journal of Finance, 59(6), 2903-2958.

Schultz, P. H., \& Zaman, M. A. (2001). Do the individuals closest to internet firms believe they are overvalued. Journal of Financial Economics, 59(3), 347-381.

Subrahmanyam, A., \& Titman, S. (2001). Feedback from stock prices to cash flows. Journal of Finance, 56(6), 2389-2413.

Terza, J. V. (1987). Estimating linear models with ordinal qualitative regressors. Journal of Econometrics, 34(3), 275-291.

von Eije, J., de Witte, M. C., \& van der Zwaan, A. H. (2004). IPO-related organizational change and longterm performance: Considerations of dutch corporate officers. Managerial Finance, 30(1), 17-28.

Welch, I. (1989). Seasoned offerings, imitation costs, and the underpricing of initial public offerings. Journal of Finance, 44(2), 421-449. 
Yosha, O. (1995). Information disclosure costs and the choice of financing source. Journal of Financial Intermediation, 4(1), 3-20.

Zingales, L. (1995). Inside ownership and the decision to go public. Review of Economic Studies, 62(3), 425-448. 